\title{
Anthropometric Comparison of Nasal Parameters between Male and Female of Gwalior Region.
}

\author{
S. K. Sharma ${ }^{1}$, Massarat Jehan ${ }^{2}$, Raj Laxmi Sharma ${ }^{3}$, Sudhir Saxena ${ }^{4}$, Akhilesh \\ Trivedi $^{5}$, Vipendra Bhadkaria ${ }^{5}$. \\ ${ }^{1}$ Associate professor (HOD), Dept of Anatomy, Gajra Raja Medical College, Gwalior (MP) India \\ ${ }^{2}$ Post Graduate Student, Dept of Anatomy, Gajra Raja Medical College, Gwalior (MP) India. \\ ${ }^{3}$ Associate professor, Dept of Pathology, Gajra Raja Medical College, Gwalior (MP) India. \\ ${ }^{4}$ Associate professor, Dept of Anatomy, Gajra Raja Medical College, Gwalior (MP) India. \\ ${ }^{5}$ Assistant professor, Dept of Anatomy, Gajra Raja Medical College, Gwalior (MP) India.
}

\begin{abstract}
:
Introduction: Nasal index is a sensitive anthropometric index. It also exhibits sexual differences and it has become a useful tool in Forensic Medicine and reconstructive surgery. It is an important anthropometric parameter for classifying the race and sex of an individual whose identity is unknown.

Aim: The present study was undertaken to provide baseline data of the nasal ergonomics for male and female of Hindu community of Gwalior region.

Material and Method: A random sample of males of 19 to 45 years age group was chosen for examination. Nasal length, nasal breadth, nasal height and nasal depth were measured with the help of Digital Vernier Caliper. Nasal index (NI) were calculated as NB/NH×100. The data was analyzed statistically using Unpaired Student $t$-test.

Result: Our results are comparable with other studies with mean NI $\pm S D$ of $80.59 \pm 9.122$ in male which was significantly higher $(p<0.05)$ than that of females who has NI \pm SD of 77.29 \pm 8.472 . Except for nasal depth, the other nasal parameters shows sexual dimorphism.

Conclusion: Based on the mean NI, the predominant nose type is Mesorrhine in $63.73 \%$ of male and female (Hindu community) of Gwalior region. This study provides a baseline data for people of Gwalior region which will be valuable in nasal anthropometry for clinical practice, in reconstructive surgery, rhinoplasty and in forensic science. This study should be subjected to further investigation.
\end{abstract}

Key words: Nasal Index, Nasal Anthropometry, Rhinoplasty, Mesorrhine.

\section{Introduction}

The nose is one of the best clues to racial origin ${ }^{1}$. Facial anthropometry has become an important tool used in genetic counseling, reconstructive surgery and forensic investigation ${ }^{2}$. Nasal Index (NI) exhibits sexual differences $^{3}$ and it has become a useful tool in Forensic Science ${ }^{4}$.

The NI is very useful in anthropology and it is one of the clinical anthropometric parameters recognized in nasal surgical and medical management ${ }^{5,6}$. NI is related to regional and climatic differences ${ }^{7,8}$. Various studies have indicated racial and ethnic differences in nasal index amongst different populations ${ }^{2,9,10}$. Nasal index measurements is one of the methods anthropologists have used to differentiate living race and subspecies of man. ${ }^{11}$

On the basis of nasal height and breadth index, Martin and Sallar (1957) ${ }^{12}$ divided noses into the following categories:

\begin{tabular}{|l|l|l|l|}
\hline Categories & Size of nose & Nasal index & On Skull \\
\cline { 3 - 4 } & & On Living head & --- \\
\hline Hyperleptorrhine & Long Narrow Nose & 40 to 54.9 & $<47$ \\
\hline Leptorrhine & Moderately Narrow Nose & $<70$ & 47 to 50.9 \\
\hline Mesorrhine & Moderate Or Medium Size & 70 to 84.9 & 51 to 57.9 \\
\hline Platyrrhine & Moderately Wide Nose & 85 to 99.9 & 58 or more \\
\hline Hyperplatyrrhine & Very Wide Nose & 100 or more & \multicolumn{2}{l}{} \\
\hline
\end{tabular}

The present study was designed to provide baseline data of certain nasal anthropometric measurements for male and female of Hindu community of Gwalior region, to determine the sexual difference and a normative data of nasal index and to classify their nose type and the comparison of the data with other studies, so that it would be further useful as an essential tool to the researchers, clinicians, rhinoplastic and facial reconstructive surgeons and forensic experts related to this field. 
Study Design: Cross sectional study

\section{Materials \& Methods}

Selection criteria: A random sample of 204 subjects, with 102 males and 102 females in the age group of 1945 years were selected. This age group were selected, as age negligibly affect the facial parameters in subject above 18years of age. The selected subject were from Hindu community of Gwalior region, whose ancestors were the residents of their respective region for at least two generations.

Exclusion criteria: Subjects who had trauma of the nose, prior plastic or reconstructive surgery of the face or cleft lips and other congenital facial malformations were excluded from the study.

Measurement procedure: All the measurement were taken with the subject sitting on a chair in a wellilluminated room, in a relaxed condition with the head in the anatomical position. The facial muscles were relaxed in order not to alter the size of the nose. Five relevant nasal surface landmarks were selected with shortest distance between two points of the nose were taken with a Digital Vernier Caliper with accuracy of 0.01 mm. The landmarks were:

1. Nasion - the point on the root of the nose where the mid-sagittal place cuts the naso-frontal suture.

2. Subnasale - the point at which the nasal septum merges with the upper cutaneous lip in the mid-sagittal plane.

3. Pronasale - the point at the tip of nose.

4. Alare - the point at the most prominent side wall of the nose.

To reduce technical error of the measurements, each measurement was taken thrice and average taken. The measurement was done by one observer to prevent inter-observer error. The measurements were:

- $\quad$ Nasal Length (NL) - measured from nasion to pronasale (Fig.1)

- $\quad$ Nasal Height (NH) - measured from nasion to subnasale (Fig.2)

- $\quad$ Nasal Breadth (NB) -maximum breadth at right angle to the nasal height from ala to ala (Fig.3)

- $\quad$ Nasal Depth (ND) - from pronasale to subnasale (Fig.4)

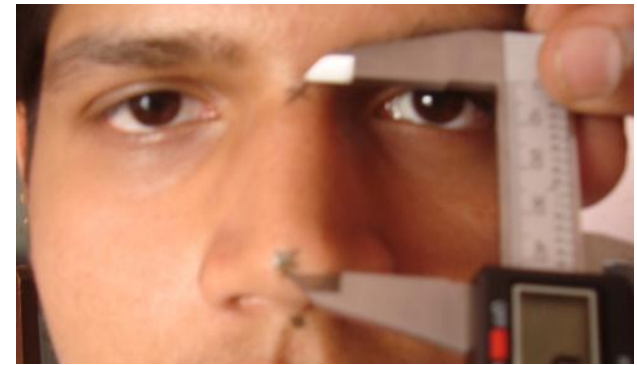

Fig.1: Showing measurement of nasal length (upper point= nasion; lower point= pronasale)

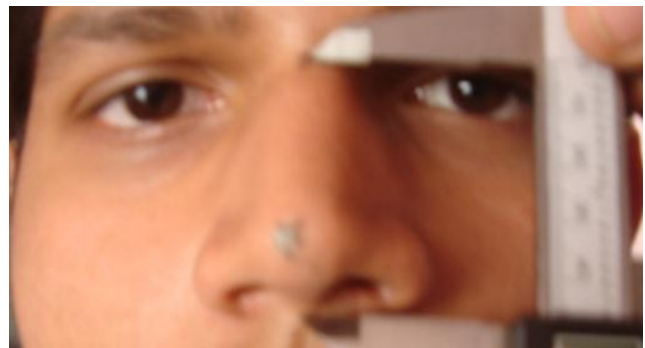

Fig.2: Showing measurement of nasal height (upper point= nasion; lower point= subnasale)

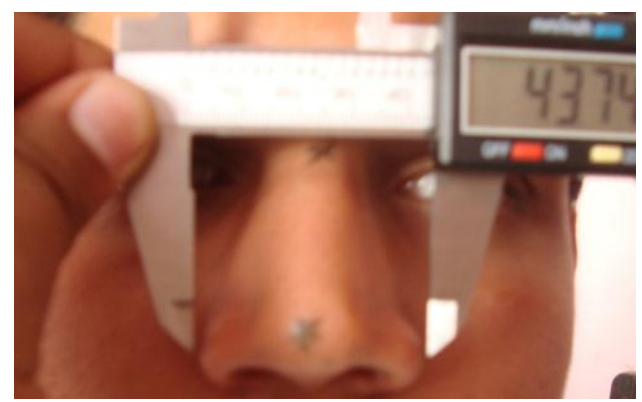

Fig.3: Showing measurement of Nasal breadth (from right ala to left ala) 


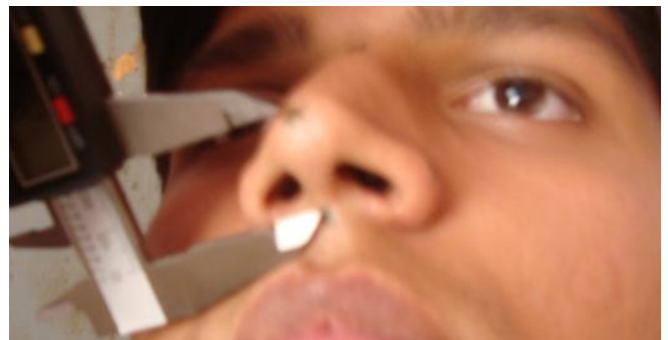

Fig.4: Showing measurement of Nasal depth (upper point= pronasale; lower point= subnasale)

The nasal indices were calculated separately for male and female group as $\rightarrow$ NB/NH x 100 .

The data was computed, tabulated and statistically analyzed using Graph Pad Prism and Microsoft Excel Windows 2007 software. The data obtained were compared with the results of other population in literature.

\section{Results}

The results of this study were presented in tabular forms (Table 1-3). The dimensions of the nasal parameters obtained in the study are shown in Table 1. Except for nasal depth, the other nasal parameters i.e. mean nasal length, breadth and height in males were significantly higher than those in females $(\mathrm{p}<0.0001)$ of Hindu community of Gwalior region.

Table 1. Descriptive statistics of different nasal parameters (No. of males $=102$ and females $=102$ )

\begin{tabular}{|l|l|l|l|l|l|l|l|l|}
\hline \multirow{2}{*}{ Mean (cm) } & \multicolumn{2}{|l|}{ Nasal Length } & \multicolumn{2}{l|}{ Nasal Height } & \multicolumn{2}{l|}{ Nasal Breadth } & \multicolumn{2}{l|}{ Nasal Depth } \\
\cline { 2 - 9 } & Male & Female & Male & Female & Male & Female & Male & female \\
\hline SD & 46.44 & 42.71 & 49.01 & 45.31 & 39.17 & 34.86 & 16.65 & 16.16 \\
\hline SEM & 3.847 & 3.647 & 4.517 & 2.878 & 2.490 & 2.892 & 2.482 & 2.451 \\
\hline Coefficient of variation & 0.3809 & 0.3612 & 0.4473 & 0.2850 & 0.2465 & 0.2863 & 0.2457 & 0.2427 \\
\hline P value (two-tailed) & $8.28 \%$ & $8.54 \%$ & $9.22 \%$ & $6.35 \%$ & $6.36 \%$ & $8.29 \%$ & $14.90 \%$ & $15.17 \%$ \\
\hline t value & $* * *$ & $* * *$ & $* * *$ & & $0.1511=\mathrm{ns}$ \\
\hline
\end{tabular}

$\mathrm{SD}=$ standard deviation; $\mathrm{SEM}=$ standard error of mean; $* * *=\mathrm{P}<0.0001 ;$ ns $=$ not significant

Descriptive statistics in Table 2, shows that the mean NI ( \pm SD) of male was $80.59 \pm 9.122$ and 77.29 \pm 8.472 for females, both of which falls under the category of Mesorrhine type of nose. This also shows that males of Gwalior region have a significantly higher NI than females $(p<0.05)$. This confirm the existence of sexual difference in nasal parameters between male and female of Gwalior region.

Table 2. Descriptive statistics of Nasal Index of Male and Female of Gwalior region

\begin{tabular}{|l|l|l|}
\hline \multicolumn{2}{|c|}{ Unpaired Student t- test } & \multicolumn{2}{c|}{ Nasal Index (NI) } \\
\cline { 2 - 3 } & Male & Female \\
\hline Minimum & 64.31 & 61.84 \\
\hline Maximum & 104.6 & 102.5 \\
\hline Mean & $\mathbf{8 0 . 5 9}$ & $\mathbf{7 7 . 2 9}$ \\
\hline SD & $\mathbf{9 . 1 2 2}$ & $\mathbf{8 . 4 7 2}$ \\
\hline SEM & $\mathbf{0 . 9 0 3 2}$ & $\mathbf{0 . 8 3 8 9}$ \\
\hline Coefficient of variation & $11.32 \%$ & $10.96 \%$ \\
\hline P value (two-tailed) & $0.0079 * *$ (significant $=\mathrm{P}<0.05)$ \\
\hline t value & $\mathrm{t}=2.682$ & \\
\hline Difference between means & $3.306 \pm 1.233$ \\
\hline 95\% confidence interval & 0.8896 to 5.722 & \\
\hline R squared & 0.03438 & \\
\hline Average mean $(\mathbf{M + F})$ & 78.94 & \\
\hline
\end{tabular}

The distribution of the nose type in Hindu community of Gwalior region were shown in Table 3. Overall the most dominant nose type was Mesorrhine with $63.73 \%$ and the least was Leptorrhine type with $14.71 \%$.

Table 3. Frequency (percentage) of nose types in male and female of Gwalior region

\begin{tabular}{|l|l|l|l|}
\hline Nose type & Males (n) & Females (n) & All n (\%) \\
\hline Leptorrhine & 12 & 18 & $30(14.71)$ \\
\hline Mesorrhine & $\mathbf{5 8}$ & $\mathbf{7 2}$ & $\mathbf{1 3 0}(\mathbf{6 3 . 7 3})$ \\
\hline Platyrrhine & 32 & 12 & $44(21.57)$ \\
\hline All & 102 & 102 & $\mathbf{2 0 4}(\mathbf{1 0 0 \%})$ \\
\hline
\end{tabular}




\section{Discussion}

The present study established that the predominant nose type to be Mesorrhine based on the mean NI of $80.59 \pm 9.122$ and $77.29 \pm 8.472$ for male and female respectively. The existence of sexual difference in nasal parameters between male and female is possibly due to many etiological factors as genetic, hormonal, nutrition and other related factors. The comparative study of our results with other literatures has been shown in Table 48 .

The statistics of nasal length estimated by different authors on different races were compared with our study in Table no. 4. Our result were comparative to those of other studies.

Table 4 - Comparison of Nasal Length of different populations

\begin{tabular}{|l|l|l|l|l|l|}
\hline \multirow{2}{*}{ Population } & \multicolumn{1}{c|}{ Author } & \multicolumn{2}{c|}{ Males } & \multicolumn{2}{c|}{ Females } \\
\cline { 3 - 6 } & & Sample size & Mean+S.D. & Sample size & Mean+S.D. \\
\hline Bheel-Meena (Rajasthan) & Gangrade $^{13}(2012)$ & 500 & 45.9 & 500 & 43.9 \\
\hline Brahmins (Punjab) & Kaushal $^{14}(2013)$ & 100 & $47.59 \pm 4.24$ & 100 & $44.09 \pm 3.79$ \\
\hline Majhabi-Sikhs (Punjab) & Kaushal $^{14}(2013)$ & 100 & $44.64 \pm 4.73$ & 100 & $41.41 \pm 2.21$ \\
\hline Muslims (Punjab) & Kaushal $^{14}(2013)$ & 100 & $45.88 \pm 4.62$ & 100 & $39.36 \pm 4.21$ \\
\hline Bekwara (Nigeria) & Esomonu $^{15}(2013)$ & 50 & $38.4 \pm 2.9$ & 50 & $39.1 \pm 2.9$ \\
\hline Ibibio (Nigeria) & Eliakim-Ikechukwu $^{16}(2013)$ & 100 & $48.1 \pm 0.4$ & 100 & $44.7 \pm 0.4$ \\
\hline Yakurr (Nigeria) & Eliakim-Ikechukwu ${ }^{16}(2013)$ & 100 & $51.6 \pm 0.4$ & 100 & $37.7 \pm 0.5$ \\
\hline Hindus(Gwalior region) & Present study & 102 & $46.44 \pm 3.847$ & 102 & $42.71 \pm 3.647$ \\
\hline
\end{tabular}

Table 5 shows the comparative study of nasal height of different populations in literature. These results were also comparable to our study.

Table 5- Comparison of Nasal Height of different populations

\begin{tabular}{|c|c|c|c|c|c|}
\hline \multirow[t]{2}{*}{ Population } & \multirow[t]{2}{*}{ Author } & \multicolumn{2}{|c|}{ Male } & \multicolumn{2}{|c|}{ Female } \\
\hline & & Sample size & Mean+S.D. & Sample size & Mean+S.D. \\
\hline Ahirwars (M.P.) & Singh and Purkait ${ }^{18}(2006)$ & 59 & 43 & 52 & 41 \\
\hline Igbos (Nigeria) & Oluto et $\mathrm{al}^{19}(2009)$ & 300 & $48.7 \pm 0.84$ & 300 & $44.6 \pm 0.74$ \\
\hline Ijaws (Nigeria) & 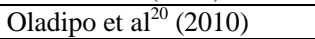 & 500 & $40.8 \pm 0.25$ & 500 & $38.9 \pm 0.30$ \\
\hline Kosovo Albanian & Staka $^{21}(2012)$ & 101 & $55.26 \pm 3.57$ & 103 & $36.90 \pm 2.67$ \\
\hline Majhabi-Sikhs (Punjab) & Kaushal $^{14}(2013)$ & 100 & $51.31 \pm 4.01$ & 100 & $48.32 \pm 2.46$ \\
\hline Muslims (Punjab) & Kaushal $^{14}(2013)$ & 100 & $53.24 \pm 4.81$ & 100 & $46.83 \pm 4.45$ \\
\hline Bekwara (Nigeria) & Esomonu $^{15}(2013)$ & 50 & $42.4 \pm 2.5$ & 50 & $42.8 \pm 2.7$ \\
\hline Hindus(Gwalior region) & Present study & 102 & $49.01 \pm 4.517$ & 102 & $45.31 \pm 2.878$ \\
\hline
\end{tabular}

The nasal breadth statistics reported by different authors on different races were compared with our study in Table 6. Our result were comparative to those of other studies.

Table 6 - Comparison of Nasal Breadth of different populations

\begin{tabular}{|c|c|c|c|c|c|}
\hline \multirow[t]{2}{*}{ Population } & \multirow[t]{2}{*}{ Author } & \multicolumn{2}{|c|}{ Male } & \multicolumn{2}{|c|}{ Female } \\
\hline & & Sample size & Mean+S.D. & Sample size & Mean+S.D. \\
\hline Latvians & Nagle et $\mathrm{al}^{17}(2005)$ & 39 & $35.3+3.2$ & 38 & $32.8+2.7$ \\
\hline Ahirwars(M.P.) & Singh and Purkait ${ }^{18}(2006)$ & 59 & 34 & 52 & 34 \\
\hline Onges(Andaman islands) & Pandey $^{22}(2006)$ & 27 & $37.8+0.6$ & 26 & $35.0+2.1$ \\
\hline Igbos (Nigeria) & Oluto et $\mathrm{al}^{19}(2009)$ & 300 & $48.7+0.84$ & 300 & $44.6+0.74$ \\
\hline Limbus (Nepal) & Shrestha $^{23}(2009)$ & 99 & $38.05+4.28$ & 118 & $37.73+3.70$ \\
\hline Ijaws (Nigeria) & 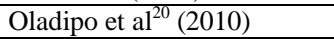 & 500 & $40.6+0.25$ & 500 & $37.9+0.25$ \\
\hline Bheel-Meena (Rajasthan) & Gangrade $^{13}(2012)$ & 500 & 38.1 & 500 & 35 \\
\hline Kosovo Albanian & Staka $^{21}(2012)$ & 101 & $36.90 \pm 2.67$ & 103 & $33.12 \pm 2.22$ \\
\hline Brahmins (Punjab) & Kaushal $^{14}(2013)$ & 100 & $37.47+4.29$ & 100 & $34.24+2.73$ \\
\hline Majhabi-Sikhs (Punjab) & Kaushal $^{14}(2013)$ & 100 & $39.66+4.55$ & 100 & $33.36+3.02$ \\
\hline Muslims (Punjab) & Kaushal $^{14}(2013)$ & 100 & $35.37+3.19$ & 100 & $31.99+1.6$ \\
\hline Hindus (Gwalior region) & Present study & 102 & $39.17 \pm 2.49$ & 102 & $34.86 \pm 2.892$ \\
\hline
\end{tabular}

Table 7 shows the comparative study of nasal depth of different populations in literature. The results were comparable to our study. 
Table 7 - Comparison of Nasal Depth of different populations

\begin{tabular}{|l|l|l|l|l|l|}
\hline \multirow{2}{*}{ Population } & \multirow{2}{*}{ Author } & \multicolumn{2}{c|}{ Male } & \multicolumn{2}{c|}{ Female } \\
\cline { 3 - 6 } & & Sample size & Mean+S.D. & Sample size & Mean+S.D. \\
\hline Brahmins (Punjab) & Kaushal $^{14}(2013)$ & 100 & $20.87+3.14$ & 100 & $17.72+3.67$ \\
\hline Majhabi-Sikhs(Punjab) & Kaushal $^{14}(2013)$ & 100 & $18.63+3.26$ & 100 & $16.97+3.09$ \\
\hline Muslims (Punjab) & Kaushal $^{14}(2013)$ & 100 & $16.53+1.65$ & 100 & $16.23+1.77$ \\
\hline Hindus(Gwalior region) & Present study $^{2}$ & 102 & $16.65 \pm 2.482$ & 102 & $16.16 \pm 2.451$ \\
\hline
\end{tabular}

The NI calculated by different authors on different races were compared along with their nose type in Table 8. It shows that the overall most common nose was Mesorrhine and Platyrrhine type. Our estimated results on Hindu community of Gwalior region were match with those of Singh and Purkait (on Dangis and Ahirwars of Madhya Pradesh), Oladipo et al (on Andoni of Nigeria) and Gangrade (on Bheel- Meena of Rajasthan) studies.

Table 8 - Comparison of Nasal Index of different populations

\begin{tabular}{|c|c|c|c|c|c|c|c|}
\hline \multirow[t]{2}{*}{ Population } & \multirow[t]{2}{*}{ Author } & \multicolumn{3}{|c|}{ Male } & \multicolumn{3}{|c|}{ Female } \\
\hline & & $\mathrm{N}$ & Mean \pm S.D. & Nose type & $\mathrm{N}$ & Mean \pm S.D. & Nose type \\
\hline Onges(Andaman islands) & Pandey $^{22}(2006)$ & 27 & $87.43 \pm 6.63$ & Platyrrhine & 26 & $90.07 \pm 7.10$ & Platyrrhine \\
\hline Ahirwars (M.P.) & $\begin{array}{l}\text { Singh and } \text { Purkait }^{18} \\
(2006)\end{array}$ & 59 & 81 & Mesorrhine & 52 & 82.4 & Mesorrhine \\
\hline Dangis (M.P.) & $\begin{array}{l}\text { Singh and } \text { Purkait }^{18} \\
(2006)\end{array}$ & 67 & 76.5 & Mesorrhine & 67 & 76.5 & Mesorrhine \\
\hline Andoni (Nigeria) & Oladipo et $\mathrm{al}^{24}(2009)$ & 200 & $79.83 \pm 4.19$ & Mesorrhine & 200 & $83.77 \pm 1.09$ & Mesorrhine \\
\hline Okrika (Nigeria) & 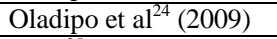 & 200 & $86.23 \pm 1.72$ & Platyrrhine & 200 & $86.46 \pm 2.37$ & Platyrrhine \\
\hline Hausa (Nigeria) & $\operatorname{Anas}^{25}(2010)$ & 224 & $70.7 \pm 11.3$ & Mesorrhine & 161 & $67.2 \pm 8.3$ & Leptorrhine \\
\hline Yoruba (Nigeria) & $\operatorname{Anas}^{25}(2010)$ & 100 & $100.9 \pm 8.9$ & Platyrrhine & 97 & $94.1 \pm 8$ & Platyrrhine \\
\hline Bini Adolescents (Nigeria) & $\operatorname{Eboh}^{26}(2011)$ & 100 & $99.13 \pm 9.26$ & Platyrrhine & 100 & $99.27 \pm 11.67$ & Platyrrhine \\
\hline Ilorin (Nigerian Africans) & ${\text { Jimoh et } \mathrm{al}^{27}(2011)}$ & 58 & 90.7 & Platyrrhine & 47 & 88.2 & Platyrrhine \\
\hline Ukwuani (Nigeria) & Eboh, John ${ }^{28}(2011)$ & - & $97.47 \pm 12.88$ & Platyrrhine & - & $98.07 \pm 8.37$ & Platyrrhine \\
\hline Bheel-Meena (Rajasthan) & Gangrade $^{13}(2012)$ & 500 & 83 & Mesorrhine & 500 & 79.73 & Mesorrhine \\
\hline Ibo (Nigeria) & $\begin{array}{l}\text { Eliakim-Ikechukwu }{ }^{29} \\
(2012)\end{array}$ & 114 & $107.62 \pm 1.09$ & Platyrrhine & 114 & $98.89 \pm 1.30$ & Platyrrhine \\
\hline Yoruba (Nigeria) & $\begin{array}{l}\text { Eliakim-Ikechukwu }{ }^{29} \\
\text { (2012) }\end{array}$ & 78 & $110.30 \pm 1.92$ & Platyrrhine & 78 & $97.07 \pm 2.11$ & Platyrrhine \\
\hline Kosovo Albanian & $\operatorname{Staka}^{21}(2012)$ & 101 & $67.07 \pm 6.67$ & Leptorrhine & 103 & $63.87 \pm 5.56$ & Leptorrhine \\
\hline Ikwerre (Nigeria) & Osunwoke $^{30}(2012)$ & 250 & 93.8 & Platyrrhine & 250 & 95.8 & Platyrrhine \\
\hline Ogu (Nigeria) & Osunwoke $^{30}(2012)$ & 250 & 95.8 & Platyrrhine & 250 & 87.34 & Platyrrhine \\
\hline Brahmins & Kaushal $^{14}(2013)$ & 100 & $70.02 \pm 9.13$ & Mesorrhine & 100 & $69.89 \pm 6.04$ & Leptorrhine \\
\hline Majhabi-Sikhs & Kaushal $^{14}(2013)$ & 100 & $76.51 \pm 8.98$ & Mesorrhine & 100 & $68.95 \pm 6.22$ & Leptorrhine \\
\hline Muslims & Kaushal $^{14}(2013)$ & 100 & $67.04 \pm 8.87$ & Leptorrhine & 100 & $69.38 \pm 8.09$ & Leptorrhine \\
\hline Bekwara (Nigeria) & Esomonu $^{15}(2013)$ & 50 & $94.65 \pm 6.42$ & Platyrrhine & 50 & $90.33 \pm 6.45$ & Platyrrhine \\
\hline Ibibio (Nigeria) & $\begin{array}{ll}\text { Eliakim } & \text { Ikechukwu }^{16} \\
(2013) & \\
\end{array}$ & 100 & $86.58 \pm 1.20$ & Platyrrhine & 100 & $81.75 \pm 1.14$ & Mesorrhine \\
\hline Yakurr (Nigeria) & $\begin{array}{l}\text { Eliakim-Ikechukwu }{ }^{16} \\
(2013)\end{array}$ & 100 & $77.76 \pm 0.82$ & Mesorrhine & 100 & $102.27 \pm 1.31$ & Platyrrhine \\
\hline Hindus(Gwalior region) & Present study & 102 & $80.59 \pm 9.122$ & Mesorrhine & 102 & $77.29 \pm 8.472$ & Mesorrhine \\
\hline
\end{tabular}

$\mathrm{N}=$ no. of subjects

Afro-American (Ofodile,1995) $)^{31}$ and Indo-African (Sparks and Jantz, 2002) ${ }^{32}$ have platyrrhine nose type. Most Caucasians and also Albanian population (Pittard, Luschan,Tildesley) ${ }^{33,34,35}$ have leptorrhine type of nose. Also, Howale ${ }^{36}$ (2012) studied 75 Dry skull of Maharashtra region and estimated the NI to be 54.30 \pm 4.19 which suggests it to be Leptorrhine type.

The present study has been able to establish the mean nasal dimensions of males and females of Hindu community of Gwalior region. It also established that as in other populations, the nasal parameters were sexually dimorphic. The result of this study will be useful in forensic medicine, anthropology and rhinoplasty and will also serve as a future framework for estimating the other craniofacial variables in same population.

\section{Conclusion}

The present study estimated the predominant nose type to be Mesorrhine in $63.73 \%$ of male and female (Hindu community) of Gwalior region, based on the mean NI of 80.59 \pm 9.122 and $77.29 \pm 8.472$ respectively. The NI of male is significantly higher than females $(\mathrm{p}<0.05)$ which confirms the existence of sexual difference in nasal parameters possibly due to genetic, hormonal, nutrition and other related factors. This study should be subjected to further investigation because of its relevance to forensic science and clinical anthropometry. This will provide a baseline data of Gwalior population which will be valuable in nasal anthropometry for clinical 
practice, in reconstructive surgery and rhinoplasty and in forensic science and therefore needs further investigation.

\section{Acknowledgement:}

We would like to express our gratitude to departmental staff and colleagues of department of Anatomy for their help and support and all the students and subjects who participated in this work.

\section{Reference}

[1] Madison G. Part I language and Nationality. In: The Passing of the Great Race 2004; 2:1-6.

[2] Oladipo GS, Olabiyi AO, Oremosu AA, Noronha CC. Nasal indices among major ethnic groups in Southern Nigeria. Scientific Res. Ess. 2007; 2(1): 20- 22.

[3] Zhang XT, Wang SK, Zhang W, Wang XF. Measurement and study of the nose and face and their correlations in the young adult of Han nationality. Plast Reconstr. Surg. 1990; 85(4):532-536.

[4] Xu B, Wang Y, Ma J, Li M, Xu L. A computer-aid study on the craniofacial features of Archang race in Yunnan province of China. Hua Xi Kou Qiang Yi Xue Za Zhi. 2011; 19(6):394-96.

[5] Hansen B, Mygind N. How often do normal persons sneeze and blow nose? Rhinol. 2002; 40(1):10-12.

[6] Zankl A, Eberle L, Molinari L, Schinzel A. Growth charts for nose length, nasal protrusion and philtrum length from birth to 97 years. Am. J. Med. Genet. 2002; 111(4):388-91.

[7] Last RJ. Anatomy Applied and Regional $6^{\text {th }}$ ed. Churchill Livingston, 1981; 398-403.

[8] Farkas LG, Kolar IR, Munro IR. Abstract on the geography of the nose, a morphometric study. Aesth. Plast. Surg.1986; 10(4):191223 .

[9] Franciscus RG, Long JC. Variation in human nasal height and breadth. Am. J. Phys. Anthropol. 1991; 85(40):419-27.

[10] Porter JP, Olson KL. Analysis of the African American female nose. Plastic Reconstruct. Surg. 2003; 111(2): 627-28.

[11] Risely HH. The People of India $2^{\text {nd }}$ ed 1915, Oriental Books, Delhi. 1969; 395-99.

[12] Martin R, Saller K. Lehrbuch der Anthropologie. Gustav Fisher Verlag. Stuttgart 1957.

[13] Gangrade PR, Babel H. Anthropometric study of the Nasal Index of the Bheel - Meena Tribe of Southern Rajasthan. IJCRR. 2012;4(19): 88-91.

[14] Kaushal S, Patnaik VVG, Kaur P. Somatometric Analysis of Nasal Morphology in the Endogamous Groups of Punjab. Hum Bio Rev 2013;2(1):1-11.

[15] Esomonu UG, Ude RA, Lukpata PU, Nandi EM. Anthropometric study of the nasal index of Bekwara ethnic group of cross river state, Nigeria. International Research Journal of Applied and Basic Sciences 2013;5(10):1262-1265.

[16] Eliakim-Ikechukwu C, Iro CM, Ihentuge CJ, Bassey TE. Nasal Parameters of Ibibio and Yakurr Ethnic Groups of South South Nigeria. IOSR-JPBS.2013;5(6):23-26.

[17] Nagle E, Teibe U, Balode I. Craniofacial morphology in parents of cleft children and healthy individuals. Stomatologija, Baltic dental and maxillofacial journal 2005;8:53-56.

[18] Singh P, Pukrait R. A Cephalometric study among Sub caste groups of Dangi and Ahirwar of Khurai block of Madhya Pradesh. Anthropologist 2006;8(3): 215-217.

[19] Olutu J, Eroje A, Oladipo GS, Edibamode E. Anthropometric study of the facial and nasal length of adult Igbo ethnic group in Nigeria. The Internet journal of Biological Anthropology 2009;2(2), viewed 29th April, 2010, <http://ISPUB.com/html>

[20] Oladipo GS, Okoh PD and Hart JS. Anthropometric study of some craniofacial parameters: Head Circumference, Nasal Height, Nasal Width and Nasal index of adult Ijaws of Nigeria. Asian journal of Medical Sciences. 2010: 2(3): 111-113.

[21] Staka G, Dragidella F, Disha M. Anthropometric Studies of Nasal Index of the Kosovo Albanian population. Antrocom Online Journal of Anthropology. 2012; 8(2): 457-62.

[22] Pandey AK. Cephalofacial variation among Onges. Anthropologist 2006;8(4):245-249.

[23] Shrestha O, Bhattacharya S, Jha N, Dhungel S, Jha CB, Shrestha S, Shrestha U. Craniofacial anthropometric measurements among Rai and Limbu community of Sunsari district of Nepal. Nepal Med Coll J 2009;11(3):183-185.

[24] Oladipo GS, Eroje MA, Fahwehinmi HB. Anthropometric comparison of nasal indices between Andoni and Okrika tribes of Rivers State, Nigeria. Int. J. Med. Med. Sci. 2009;1(4):135-137.

[25] Anas IY, Saleh MS. Anthropometric Comparison of Nasal Indices between Hausa and Yoruba Ethnic Groups in Nigeria. Journal of Scientific Research and Reports. 2010;3(3):437-444.

[26] Eboh DEO. Nasal Indices among Bini Adolescents in Edo State, Nigeria. Int. J. Morphol. 2011;29(4):1231-1234.

[27] Jimoh RO, Alabi SB, Kayode AS, Salihu AM, Ogidi OD. Rhinometry: spectrum of nasal profile among Nigerian Africans. Braz. j. otorhinolaryngol. 2011;77(5):589-93.

[28] Eboh DEO, John EA. Morphological assessment of face and nose shapes among the Ukwuanis of Delta state, Nigeria. J. Exp. Clin. Anat. 2011;10(1):4-8

[29] Eliakim-Ikechukwu C, Bassey T, Ihentuge C. Study of the Nasal Indices and Bialar Angle of the Ibo and Yoruba Ethnic groups of Nigeria. J. of Biol. Agric. and Healthcare 2012;2(11):149-152.

[30] Osunwoke EA, Oladipo GS, Ordu KS, Paul CW. Anthropometric Study of the Cephalic and Nasal Indices of Ogu and Ikwerre People of Nigeria. Current Research Journal of Biological Sciences 2012;4(1):1-3.

[31] Ofodile FA, Bokhari F. The African American nose: part II. Ann Plast Surg. 1995; 34:123-29.

[32] Sparks CZ, Jantz RL. A reassessment of human cranial plasticity: boas revisited. Proceeding of the National Academy of Sciences 2002; 99:14636-39.

[33] Pittard E. Anthropologie de la Roumanie - Les peuples sporadiques. Contribution à l' étude anthropologique des Albanais, recontrés principalement dans la Dobrodja 1910; 395-438.

[34] Luschan von F. Völker, Rassen, Sprachen 1922; 63

[35] Tildesley ML. The Albanians of the North and South 1933; 21-52.

[36] Howale DS, Jain LK, Iyer K, Lekharu R. Orbital and nasal indices of Maharashtra region: a direct measurement study using dry skulls. International Journal Of Current Research 2012;4(8):158-161. 